\title{
WORKS IN PROGRESS
}

\author{
SENECA y CELESTINA \\ Louise Fothergill-Payne
}

El proyecto de investigación anunciado en Celestinesca (Mayo 1980) está avanzando hasta tal punto que dentro de breve estará listo el estudio para su publicación.

Se trata de las Epistulas de Séneca, así como sus tragedias, los tratados morales (de Ira, de Clementia, de Providentia, de Vita Beata) y los escritos del "pseudo-Séneca" (Proverbios, admonestamientos, recopilación), que fueron traducidos al castellano en el siglo $X V$ y que en su conjunto constituyeron un verdadero ars vivendi en visperas del Renacimiento.

Estos escritos no dejaron de impresionar al autor (los aụtores) de Celestina en tal medida que se puede considerar la Tragicomedia como un libro hondamente senequista. La deuda del compositor de Celestina para con Séneca se manifiesta no sólo a través de las numerosas citas textuales (muchas más de las que hasta ahora se han registrado), sino también en lo que se refiere a la temática de los conflicos dramáticos, $v$. gr. la amistad "por provecho y ganancia" equiparada con "el loco amor de los enamorados" (Ep. 9) o el trato intimo con el vulgo "la gracia y el favor del cual se gana por mala arte" (Ep. 32). Lugar prominente en los escritos de Séneca lo ocupa además el problema de cómo tratar a los criados $y$, relacionado con él, la cuestión de cómo recompensarlos. Además de encontrar los nombres de Calisto y Melibea en las Epistulas, se delinea en éstas el retrato de todos los personajes de Celestina cuyas vidas, obras y palabras están en tan flagrante, contradicción al principio estoico de "vivir según la natura" (=vivir a su ley).

Ya se han dado varias conferencias mias en distintos lugares, conferencias que han resaltado diferentes aspectos senequistas en Celestina: en St. Andrew's University, el tema de la servitud en en Centro "Dámaso Alonso" de la SUNY-Albany, sobre el "vivir según los dictámenes de la naturaleza"; $y$, recientemente, en el VIII Congreso de la Asociación Internacional de Hispanistas, sobre la codicia como vicio que, bajo una u otra forma, domina a todos los personajes de Celestina.

\section{CELESTINA: DIALOGUE AS MIRROR OF PARODY Elena Gascón Vera}

The title of my monograph/project relates to the ways in which Fernando de Rojas, through the use of dialogue, calls into question the materials and codes of traditional literature, such as courtly love, stoic philosophy, chivalric manners, paternalistic authority, etc. in order to destroy them. 
Celestina has received limited critical attention from comparative literary critics, especially when one considers the disproportionate merit and importance of the work as the greatest of those which were to influence Cervantes. Recently developed tools in literary criticism have contributed to a re-thinking and re-elaboration of the concept of literature, affording both the critic and the reader a new perspective and opportunity for a study of Celestina.

One such critical view is Mikhail Bakhtin's. He has used linguistic, semiotic, and sociological approaches together to reconsider the idea of literature (and particularly the novel) as a constant process of dialogue at many different levels. These approaches could be used as a frame for a critical work on Rojas' masterpiece and this is what I am now preparing. Bakhtin's work, though central to my project, will be used eclectically in conjuntion with the work of other critics (Saussure, Freud, inter alios) in order to present Celestina in a new critical light which will have pluralistic emphases.

The monograph, when completed, will present new viewpoints about Celestina that, to my knowledge, have not been set forth previously. The critical theory used is as present time little known or used by critics of Hispanic literatures and perhaps this study will help critics to see its potential for application to other Hispanic works.

\section{CONCORDANCIAS DE CELESTINA \\ J. Múñoz Garrigós \\ Murcia}

Se piensa llevar a cabo una concordancia de la Tragicomedia como primer tomo en una serie de estudios léxicos sobre la obra de Rojas. Consistirá 'de tres bloques diferentes: en el primero se incluirá el texto de la Tragicomedia, sin prolegómenos ni argumentos de cada acto

en el segundo aparecerán los argumentos y las estrofas finales del editor; en el tercero vendrán todos los prolegómenos y las estrofas de conclusión del propio Fernando de Rojas. Como apéndice va el "Aucto de. Trasso." Con esto, se deslindará, desde el punto de visto lexicográfico, la Tragicomedia de los demás escritos de Rojas y de lo que añadieron sus editores. [Es evidente que el primer acto, si no fue escrito por el autor de los restantes, como parece obvio, fue aceptado, en la forma en que hoy lo conocemos, por él, por lo que, ya que no la paternidad, hay que atribuirle la total conformidad.] 